\title{
An evaluation of chromium and zinc biosorption by a sea weed (Sargassum sp.) under optimized conditions \\ A. Saravanan ${ }^{1}$, V.Brindha ${ }^{2}$, R. Manimekalai ${ }^{2}$ and Soundarajan Krishnan ${ }^{1}$ \\ ${ }^{1}$ Department of Chemical Engineering, Sathyabama University, Chennai - 119, India. \\ ${ }^{2}$ Department of Bioinformatics, Dr.MGR Janaki College, Chennai-28, India.
} saranbiotech2006@gmail.com, brindhav2@gmail.com

Abstract: Biosorption is a promising alternative method to treat industrial effluents, mainly because of its low cost and high metal binding capacity. In this work, Zinc and Chromium biosorption process by Sargassum $s p$. seaweed biomass was studied. The work considered the determination parameters of Zinc and Chromium sorption such as $\mathrm{pH}$, temperature, agitation speed and biomass size. The optimum conditions were: $\mathrm{pH} 3$, temperature $(303 \mathrm{k})$ room temperature, biomass size $0.5 \mathrm{~mm}$ and agitation speed 150rpm. The maximum uptake of Chromium and Zinc is $65 \%$ and $53 \%$ respectively. The kinetic study revealed that the adsorption of Chromium and zinc by Sargassum $s p$. fitted the Langmuir isotherm.

Keywords: Biosorption, chromium, zinc, heavy metal, Sargassum sp.

Introduction

Heavy metal pollution of waste water is a common environmental hazard, since the toxic metal ions dissolved can ultimately reach the top of the food chain and thus become a risk factor for human health. This metals are present in the waste water of several industries such as metal cleaning and plating baths, refineries, paper and pulp, tanning industries etc (Periasamy \& Namasivayam, 1996; Ghazy et al.,2008). The excessive intake of metal by man leads to severe mucosal irritation, widespread capillary damage, hepatic and renal damage, central nervous problems followed by depression, gastrointestinal irritation and possible necrotic changes in the liver and kidney (Kalavathy et al., 2005). For more than a decade, researchers have been looking for cheaper and more effective methods to remediate heavy metal contaminated waters and reduce the growing public health risk. Biosorption is proven to be quite effective at removing metals ions from contaminated solution in a low-cost and environment-friendly manner (Volesky, 1990) The major advantages of biosorption over conventional treatment methods include low cost, high efficiency of metal removal from dilute solution, minimization of chemical and/or biological sludge, no additional nutrient requirement, regeneration of biosorbent and the possibility of metal recovery (Kratochvil \& Volesky, 1998). Marine macro-algae are harvested or cultivated in many parts of the world and are therefore readily available in large quantities for the development of highly effective biosorbent materials. Chromium, Zinc, like the majority of heavy metals, is toxic but it has been widely used in metallurgical and tanning industries. Chromium deficiency in humans results in symptoms comparable to those associated with diabetes (Aksu et al., 1999). The objective of the present work was to evaluate chromium and zinc biosorption by Sargassum $s p$., and also to evaluate the influence of different parameters on zinc and chromium uptake such as $\mathrm{pH}$, temperature, agitation and size of the biomass was investigated and the maximum biosorption capacity of the biomass, based on dry weight was determined from the equilibrium data measured under optimized conditions of $\mathrm{pH}$ and modeled according to Langmuir model. The main reason for the extended use of Langmuir model was that they incorporate easily interpretable constants (Davis et al., 2007). The Langmuir sorption isotherm has traditionally been used to quantify and contrast the performance of different biosorbents. In its formulation, binding to the surface was primarily by physical forces and implicit in its deviation was the assumption that all sites possess equal affinity for the sorbate. Its use was extended to empirically describe the equilibrium relationships between the bulk liquid and solid phases (Azizian, 2006).

\section{Materials and Methods}

\section{Preparation of biomass}

The biomass used in the present study was the brown seaweed Sargassum $s p$., collected from the southern coast of India. After harvesting from sea, the samples were washed with distilled water to remove particulate materials and salts from the surface. They were then dried in an oven at $60^{\circ} \mathrm{C}$ for $24 \mathrm{hrs}$ and then used as biosorbent for further studies (Da costa \& De franca, 1997).

Synthetic effluent and metal ions analysis

Analytical grade $\mathrm{ZnSO} 4.7 \mathrm{H}_{2} \mathrm{O}$ and $\mathrm{K}_{2} \mathrm{Cr}_{2} \mathrm{O}_{7}$ were dissolved in distilled water in order to obtain a solution containing zinc and 
Fig. 1. Chromium removal by Sargassum $s p$. at different $\mathrm{pH}$ conditions

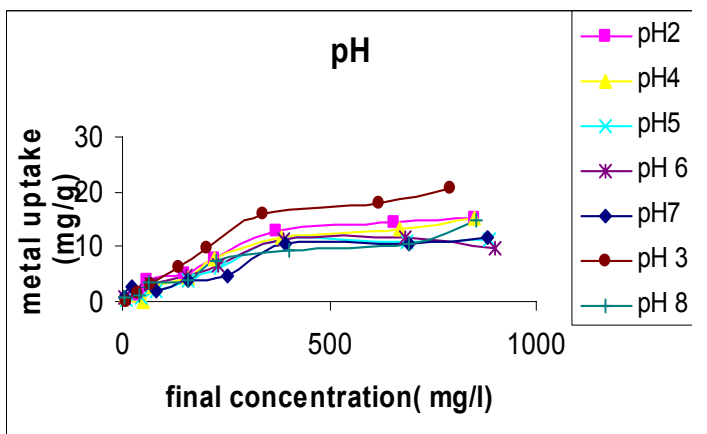

Fig 3. Effect of algal size on the removal of chromium ions

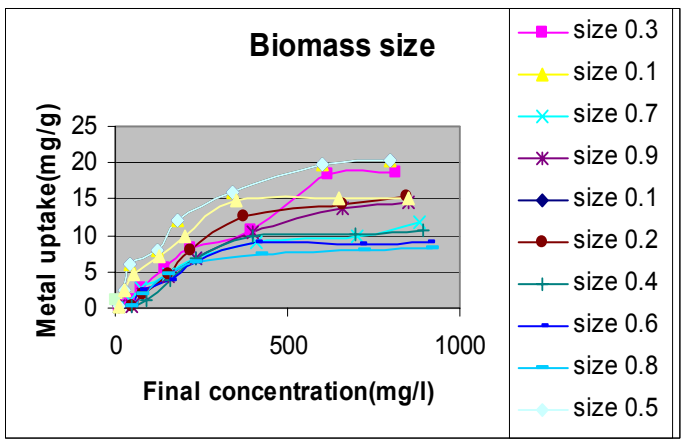

Fig 5. Adsorption capacity of chromium at different temperature

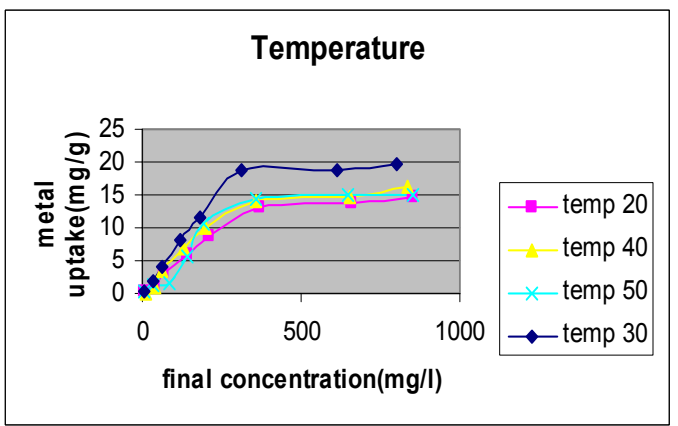

chromium. This solution was used for metal biosorption experiments. Concentrations of standard and process solutions were evaluated by Atomic Absorption Spectrometry (AAS6VARIO; Analytik jena, Germany). Batch Experiments

Batch biosorption experiments were performed by adding $0.1-1.0 \mathrm{mg}$ of dried biomass to $100 \mathrm{ml}$ of metal solution in $250 \mathrm{ml}$ Erlenmeyer flasks. The flasks were agitated at $150 \mathrm{rpm}$. The experiments were conducted at room temperature. For studying the influence of $\mathrm{pH}$ on the biosorption, experiments were conducted at various initial metal solution $\mathrm{pH}$ values of 3-8. Metal free and biosorbent free blanks were used as control. The residual ion concentration in the solution was analyzed using atomic absorption spectrometry. http://www.indjst.org Vol.2 No 1 (Jan. 2009)

Fig. 2. Zinc removal by Sargassum sp.at different $\mathrm{pH}$ conditions

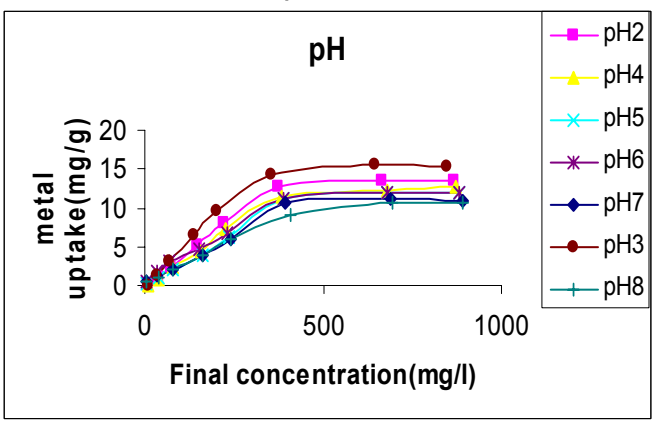

Fig 4.Effect of algal size on the removal of zinc ions

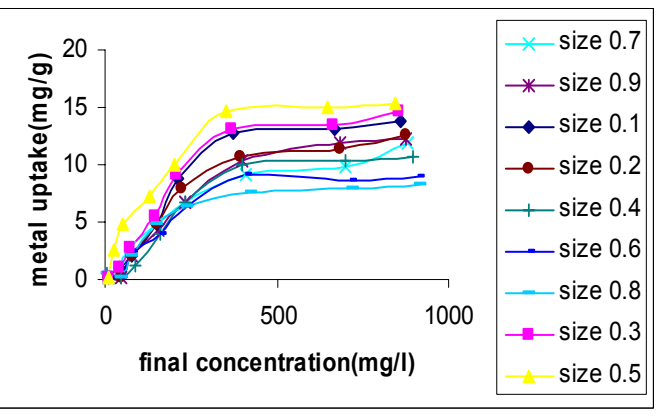

Fig 6. Adsorption capacity of zinc at different temperature

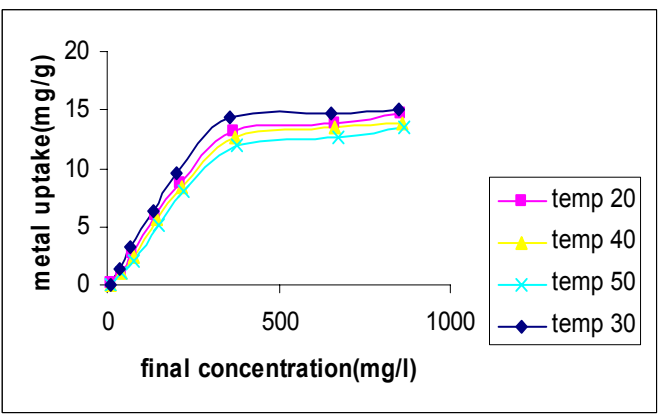

Equilibrium study of metal ion adsorption by seaweed biomass

The empirical form of the Langmuir adsorption isotherm equation is given as:

$$
q_{e}=\frac{b_{e} q_{\max }}{1+b C_{e}}
$$

And the linear form is given as:

$$
\frac{\mathrm{C}_{\mathrm{e}}}{\mathrm{q}_{\mathrm{e}}}=\frac{1}{\mathrm{q}_{\max }} \mathrm{C}_{\mathrm{e}}+\frac{1}{\mathrm{q}_{\max } \mathrm{b}}
$$

Where $q_{e}$ is the removal capacity of metal $\mathrm{mg} / \mathrm{g} . \mathrm{C}_{e}$ is the equilibrium concentration of metal ions in solution $\mathrm{mg} / \mathrm{L}, q_{\max }$ is the maximum adsorption capacity (unit:mg/g or $\mathrm{mmol} / \mathrm{g}$ ), and $b$ is the affinity constant (unit:L/mg or L/mmol). 
Indian Journal of Science and Technology

Fig 7. Adsorption capacity of chromium at different agitation speed

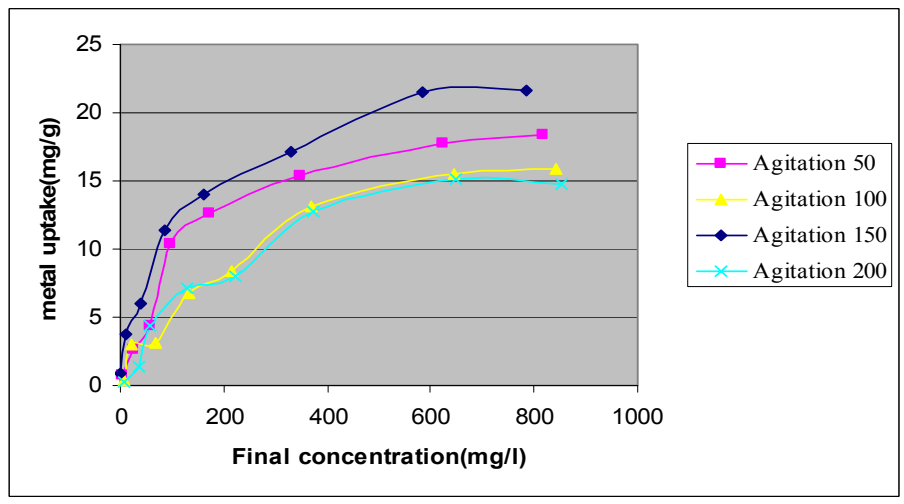

Fig 8. Adsorption capacity of zinc at different agitation speed

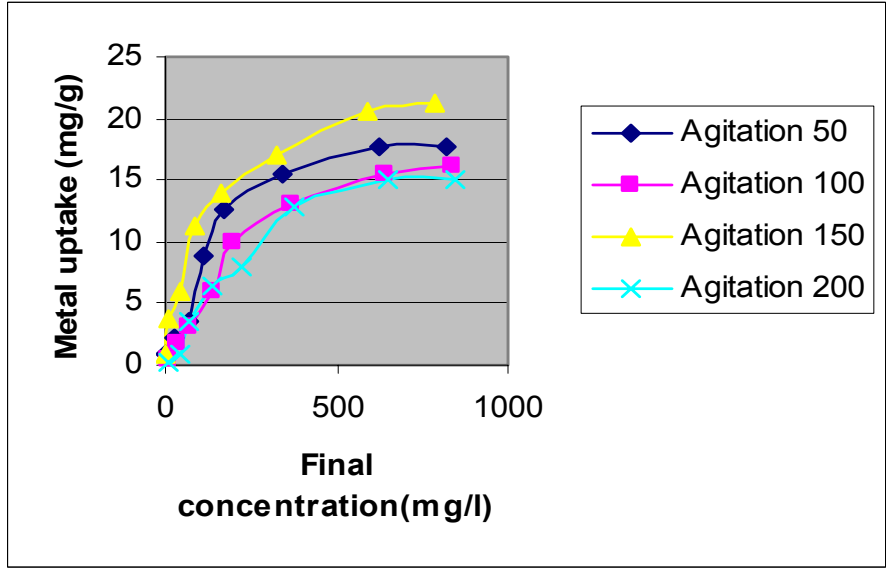

Fig 9. Kinetics of chromium and zinc biosorption by Sargassum $s p$.

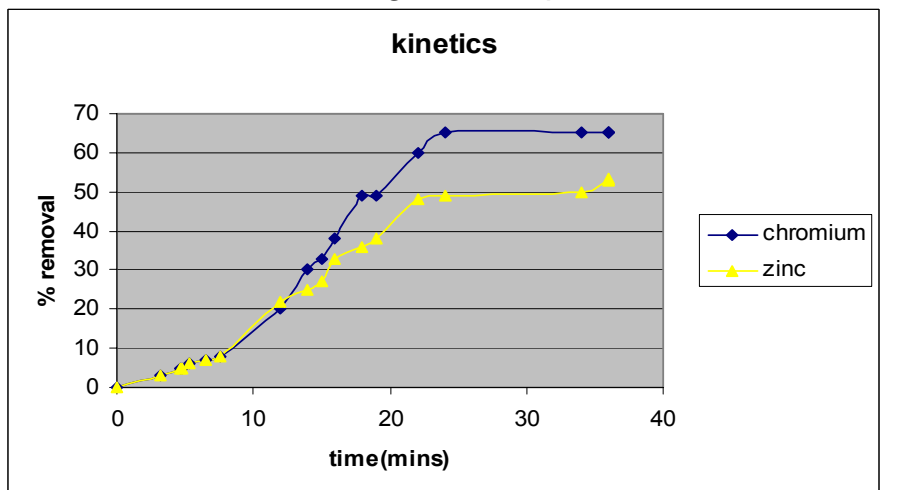

The Freundlich isotherm holds most of the assumptions suggested in Langmuir isotherms, except that it assumes that sorption takes place on a heterogeneous surface and the binding sites are not equivalent and/or independent (Aksu et al., 1999. The empirical Freundlich adsorption isotherm equation (Volesky, 1990) is given as:

$$
\mathrm{q}_{\mathrm{e}}=\mathrm{kC}_{\mathrm{e}}{ }^{1 / \mathrm{n}}
$$

This equation can be linearized by taking natural $\log (\mathrm{In})$ and given the following form: http://www.indjst.org Vol.2 No 1 (Jan. 2009)

$$
\ln \mathrm{q}_{\mathrm{e}}=\ln \mathrm{k}+\frac{1}{\mathrm{n}} \mathrm{C}_{\mathrm{e}}
$$

Where $\mathrm{q}_{\mathrm{e}}$ is the removal capacity of metal $\mathrm{mg} / \mathrm{g}, \mathrm{k}$ is the adsorbent capacity and $\mathrm{I} / \mathrm{n}$ is the adsorption intensity.

\section{Result and Discussion}

Effect of initial solution $\mathrm{pH}$

Marine algae contain high content of ionizable groups (carboxyl from mannuronic and guluronic acids) on the cell wall polysaccharides, which suggests that the biosorption process could be affected by changes in the solution pH (Matheickal \& Yu; 1999 Davis et al., 2000). It was observed that the uptake of chromium and zinc was higher at $\mathrm{pH} 3$ (Fig.1 \& 2). The maximum uptake of chromium and zinc at $\mathrm{pH} 3$ is $20.64 \mathrm{mg} / \mathrm{g}$ and $15.40 \mathrm{mg} / \mathrm{g}$ respectively.

\section{Effect of algae size}

The effect of Sargassum $s p$. (biomass) on the removal of chromium and zinc was studied in the size range of $0.1-1 \mathrm{mg}$. Fig. 3 \& 4 showed the maximum uptake was attained at the size of $0.5 \mathrm{mg}$ of algal biomass and the maximum uptake of chromium and zinc is $20.24 \mathrm{mg} / \mathrm{g}$ and $15.43 \mathrm{mg} / \mathrm{g}$ respectively.

\section{Effect of temperature}

The uptake of chromium and zinc ions by Sargassum $s p$. was evaluated varying the temperature from $20-50^{\circ} \mathrm{C}$. Fig. 5 \& 6 shows that chromium and zinc uptake was increases at room temperature and the maximum uptake was $19.83 \mathrm{mg} / \mathrm{g}$ and $16.38 \mathrm{mg} / \mathrm{g}$ respectively.

\section{Effect of agitation}

The maximum uptake was attained at $150 \mathrm{rpm}$ and the uptake of chromium and zinc was $21.60 \mathrm{mg} / \mathrm{g}$ and $21.32 \mathrm{mg} / \mathrm{g}$ respectively (Fig. 8 \&).

Equilibrium study of metal ion adsorption

The purpose of these experiments was to determine the contact time required to reach the equilibrium. Fig. 9 shows the kinetic tests of sorption for chromium and zinc at different concentrations. The metallic ion fraction removed from solution was calculated by the following expression:

$$
f j=\frac{\left(C j^{0}-C j(t)\right)}{\left(C j^{0}-C j^{*}\right)}
$$


Chromium removal is faster than zinc removal (Fig.9). Contact time for equilibrium is a function of several factors: biomass type (number and types of metal-binding sites), size and forms of biomass, state of biomass (active or inactive, free or immobilized), etc. The results of kinetic biosorption tests showed that approximately $53 \%$ of zinc and $65 \%$ of chromium had been removed. Based on Langmuir isotherm models, biomass of Sargassum $s p$. can be classified as a good biosorbent. A Langmuir isotherm allows to calculate the maximum metal uptake values and an affinity parameter indicative of the binding energy between the adsorbed solute molecules and the adsorbent (Ho et al., 2008). The Langmuir adsorption model described well the biosorption equilibrium of chromium and zinc ions Sargassum $s p$. Langmuir isotherm parameters were used to determine the affinity of one metal for the biosorbent in the presence of the other metal.

\section{Reference}

1. Aksu Z, Acikel U and Kutsal T (1999) Investigation of simultaneous Biosorption of copper (II) and chromium (IV) on dried Chlorella vulgaris from binary metal mixtures: application of multicomponent adsorption isotherms. Separation Sci.Technol. 34, 501-524.

2. Azizian S (2006) Kinetic models of sorption: theoretical analysis. J.Colloid Int.Sci. 276, 47-52. Da costa ACA and De franca FP (1997) Biosorption of zinc, cadmium and copper by a brown sea weed (Sargassum $s p$.) in a continuous fixed-bed laboratory reactor. Bioseparation. 6, 335341.

3. Davis TA, Volesky B and Mucci (2007) A review of the biochemistry of heavy metal biosorption by brown algae. Water Res. 37, 4311-4330.

4. Davis TA, Volesky B and Vieira RHSF (2000) Sargassum seaweed as biosorbent for heavy metals. Wat.Res. 34, 4270-4278.

5. Ghazy SE, El-Asmy AA and EL-Nokrashy AM (2008) Separation of chromium (III) and chromium(VI) from environmental water samples using eggshell sorbent. Indian J. Sci. Technol. 1 (6), 1-7. Domain site: http://www.indjst.org.

6. Ho YS, Ng JCY and McKay G (2008) Kinetics of pollutant sorption by biosorbents: review. Sep.Purif.Meth. 29, 189-232.

7. Kalavathy $\mathrm{MH}$, Karthikeyan $\mathrm{T}$, Rajagopal $\mathrm{S}$ and Miranda LR (2005) Kinetics and isotherm studies of $\mathrm{Cu}(\mathrm{II})$ adsorption onto $\mathrm{H}_{3} \mathrm{PO}_{4}$ - activated rubber wood saw dust. $J$. Colloid Interface Sci. 292, 354-362.

8. Kratochvil D and Volesky B (1998) Advances in the biosorption of heavy metals. Trends Biotech. 16, 291-300.

9. Matheickal JT and Yu O (1999) Biosorption of lead (II) and copper (II) by pre-treated biomass of Australian marine algae. Bioresource Tech. 69, 223-229.

10. Periasamy K and Namasivayam C (1996) Removal of Copper (II) by adsorption onto peanut hull carbon from water and copper plating industry waste water. Chemosphere. 32, 769-789.

11. Volesky B (1990) Biosorption and biosorbents. In biosorption of heavy metals, CRC press, Florida. pp:3-6. 